\title{
Praktikalitas Modul Asam Basa Berbasis Inkuiri Terbimbing Kelas XI MIPA
}

\section{Practicality of the Guided Inquiry Based Acid-Base Module for Class XI MIPA}

\author{
M Shafitri ${ }^{1}$ and Iryani ${ }^{1^{*}}$ \\ ${ }^{1}$ Pendidikan Kimia, Universitas Negeri Padang, \\ Jl. Prof. Dr. Hamka, Air Tawar Barat, Padang Utara, Sumatera Barat, Indonesia 25171 \\ *iryaniachmad62@gmail.com
}

\section{ARTICLE INFO}

Received on:

29 September 2021

Revised till:

30 October 2021

Accepted on:

30 October 2021

Publisher version published on:

01 November 2021

\begin{abstract}
This study aims to determine the practicality of the guided inquiry-based acid-base module in class XI MIPA. This study uses a plomp development model consisting of three stages, namely initial research, prototype development, and the assessment stage. The instrument used in the practicality test is in the form of a questionnaire given to teachers and students. The practicality value is calculated by using Aiken's $V$ formula. The result of this study indicates that the module developed has a practical value of 0,89 with a high category.
\end{abstract}

\section{KEYWORDS}

Asam Basa, Guided Inquiry, Module, Plomp, Practicality

\begin{abstract}
ABSTRAK
Penelitian ini bertujuan untuk mengungkapkan kepraktisan dari modul asam basa berbasis inkuiri terbimbing pada kelas XI MIPA. Penelitian menggunakan model pengembangan Plomp terdiri dari tiga tahap, yaitu preliminary research, prototyping research, dan assessment phase. Instrumen yang digunakan pada uji praktikalitas adalah berupa angket yang diberikan kepada guru dan peserta didik. Nilai kepraktisan dihitung menggunakan formula Aiken's V. Hasil dari penelitian ini menunjukkan bahwa modul yang dikembangkan memiliki nilai kepraktisan 0,89 dengan kategori tinggi.
\end{abstract}

KATA KUNCI

Asam Basa, Inkuiri Terbimbing, Modul, Plomp, Praktikalitas 


\section{PENDAHULUAN}

Kurikulum adalah hal yang penting dalam pembelajaran. Kurikulum 2013 dirancang untuk meningkatkan kemampuan peserta didik dari sisi pengetahuan dan keterampilan ${ }^{[1]}$. Kurikulum 2013 revisi 2018 menjelaskan mengenai pembelajaran bukan hanya proses penyaluran ilmu pengetahuan yang diberikan dari guru ke peserta didik, tetapi mereka diminta untuk berpikir kritis, mencari, mengolah, dan mengkonstruksi pengetahuan dalam proses pembelajaran ${ }^{[2]}$. Peserta didik bisa meningkatkan pemahaman pada materi yang bersifat abstrak yaitu dengan cara meningkatkan keterampilan peserta didik dalam mengkonstruksi suatu konsep ${ }^{[3]}$. Hal ini dapat dilakukan dengan bantuan bahan ajar yang terdiri dari makroskopik, submikroskopik ataupun simbolik.

Strategi pembelajaran kimia pada kurikulum 2013 salah satunya yaitu strategi pembelajaran inkuiri dengan pengertian inkuiri dalam bahasa inggris, berarti pertanyaan, atau pemeriksaan, penyelidikan. Salah satu tingkatan dari model pembelajaran inkuiri yaitu model pembelajaran inkuiri terbimbing ${ }^{[4]}$. Model pembelajaran inkuiri terbimbing terdapat 5 tahap pembelajaran ialah orientasi, eksplorasi, pembentukan konsep, aplikasi dan penutup ${ }^{[5]}$.

Pembelajaran berbasis inkuiri terbimbing mampu mengembangkan pemahaman peserta didik dengan mengikutsertakan peserta didik dalam proses kegiatan pembelajaran secara aktif, sehingga konsep yang dicapai lebih baik ${ }^{[6]}$. Selain itu didapatkan bahwa peserta didik dengan kelompok belajar menggunakan inkuiri terbimbing memiliki pemahaman yang lebih baik terhadap pemahaman konsep pelajaran dan menunjukkan semangat belajar.

Pembelajaran dapat dilakukan dengan bahan ajar yang dapat menjadikan mereka berpikir kritis salah satunya adalah menggunakan bahan ajar berupa modul. Modul adalah bahan ajar berupa cetakan yang dilengkapi dengan petunjuk untuk belajar. Modul yang digunakan berbasis inkuiri terbimbing berisi tahapan pembelajaran inkuiri terbimbing ${ }^{[7]}$. Sehingga peserta didik dapat belajar secara mandiri dan memahami konsep yang dipelajari ${ }^{[8]}$.

Modul berbasis inkuiri terbimbing yang telah dikembangkan sebelumnya yaitu validitas dan praktikalitas modul reaksi oksidasi dan reduksi berbasis inkuiri terbimbing dilengkapi soal high order thinking skill (HOTS) untuk siswa kelas X SMA/MA oleh Iryani dan Bahri dengan hasil validitas 0,77 dan praktikalitas respons guru dan peserta didik yaitu 0,80 dan 0,70. Sehingga modul berbasis inkuiri terbimbing memiliki tingkat validitas dan praktikalitas yang tinggi pada pembelajaran kimia SMA ${ }^{[9]}$.

Materi asam basa merupakan materi pokok pada kelas XI SMA di semester genap. Hasil dari wawancara dan pembagian angket peserta didik di sekolah oleh peneliti sebelumnya, diperoleh bahwa sekolah sudah menggunakan kurikulum 2013. Bahan ajar masih menggunakan LKPD/LKS dan buku teks dengan tampilan yang kurang menarik, belum dilengkapi soal tipe HOTS, penyajian bahan ajar belum melingkupi tiga level representasi, juga nilai agama dan nilai budaya Minangkabau belum terintegrasi di sekolah.

Penelitian yang dilakukan oleh Yolanda dan Iryani (2020), telah mengembangkan modul asam basa berbasis inkuiri terbimbing pada peserta didik Kelas XI MIPA. Berdasarkan hasil penelitian didapatkan bahwa modul yang dikembangkan mengungkapkan kategori validitas tinggi dengan nilai 0,89; namun belum dilakukan uji praktikalitasnya. Sehingga dilaksanakan penelitian lanjutan yang berjudul "Praktikalitas Modul Asam Basa Berbasis Inkuiri Terbimbing Kelas XI MIPA".

\section{METODE}

Penelitian lanjutan ini dilaksanakan di SMA N 1 Ampek Nagari, Kecamatan Ampek Nagari, Kabupaten Agam. Penelitian ini adalah pengembangan penelitian Research and Development (R \& D) untuk memperluas dan menghasilkan bahan ajar berupa modul yang berbasis inkuiri terbimbing terhadap hasil belajar peserta didik ${ }^{[10]}$.

Penelitian menggunakan tahapan pengembangan model Plomp terdapat 3 tahapan, yaitu preliminary research atau penelitian awal, prototyping research atau pengembangan prototipe, dan assessment phase atau tahap penilaian $^{[11]}$. Tahap preliminary research atau penelitian awal ini mengenai analisis kebutuhan, analisis konteks (isi), dan studi literatur serta pengembangan kerangka konseptual ${ }^{[12]}$.

Tahap pengembangan prototipe merupakan tahapan untuk menghasilkan prototipe pada penilaian evaluasi formatif. Tahapan ini dilakukan uji coba produk dan dilakukan revisi melalui evaluasi formatif. Selanjutnya tahap assessment phase atau tahap penilaian merupakan penilaian dari produk akhir yang dihasilkan melalui evaluasi (semi-) sumatif ${ }^{13]}$.

Penelitian ini merupakan penelitian lanjutan mengenai modul asam basa berbasis inkuiri terbimbing oleh Tika Yolanda (2020). Penelitian ini telah sampai pada tahap prototipe III dimana produk sudah dikatakan valid. Metode penelitian ini dimulai pada tahap berikut:

\subsection{Tahap Prototipe IV}

Tahap ini dilakukan evaluasi setelah produk dikatakan valid pada prototipe III.Evaluasi dilakukan melalui uji kelompok kecil (small group) dengan memilih enam orang peserta didik yang memiliki tingkat kemampuan berbeda sesuai usulan dari guru kimia di sekolah tersebut ${ }^{[14]}$. Selanjutnya akan diberikan modul kepada peserta didik, pertanyaanpertanyaan dari modul akan dijawab oleh peserta didik. Setelah diberikan modul akan diberikan angket yang dapat menentukan kepraktisan modul. Jika masih ada kekurangan akan dilakukan revisi sehingga diperoleh prototipe IV yang telah praktis. Selanjutnya akan dilakukan evaluasi (semi-) sumatif dengan uji lapangan. 


\subsection{Tahap Penilaian}

Tahap ini merupakan hasil akhir produk yang telah praktis digunakan terhadap peserta didik. Tahap ini dilakukan evaluasi (semi-) sumatif bertujuan untuk melihat apakah produk dapat digunakan di lapangan dan memperoleh praktikalitas dari prototipe IV yang dihasilkan. Uji praktikalitas dilakukan dengan memberikan angket kepada guru dan peserta didik.

\subsubsection{Uji praktikalitas guru}

Tahap ini guru akan mengisi angket sesuai arahan peneliti dengan memperlihatkan modul yang dihasilkan. Modul digunakan oleh guru berdasarkan petunjuk yang disediakan dan mengisi angket yang telah disediakan.

\subsubsection{Uji praktikalitas peserta didik}

Tahap ini peserta didik menggunakan dan menjawab pertanyaan yang ada pada modul. Selanjutnya mereka diminta mengisi angket yang telah disediakan.

Penelitian ini meliputi uji praktikalitas guru dan uji praktikalitas peserta didik yang diuji dari pemberian angket. Angket praktikalitas berisikan pertanyaan mengenai kemudahan penggunaan modul dari segi bahasa, tulisan dan lainnya; efisiensi waktu belajar menggunakan modul dan manfaat dari menggunakan modul. Uji praktikalitas menggunakan teknik analisis Aiken's $\mathrm{V}^{[15-16]}$. Penilaian dengan memakai formula rumus Aiken's V yang bisa dilihat pada Persamaan 1, dan Persamaan 2.

$$
\begin{gathered}
V=\frac{\sum s}{n(c-1)} \ldots \text { Persamaan } 1 . \\
s=r-I o \ldots \text { Persamaan } 2 .
\end{gathered}
$$

Simbol-simbol pada Persamaan 1 dan Persamaan 2, melambangkan hal-hal berikut, yakni: $I o$ = Skor terendah dalam kategori (dalam hal ini $=1) ; c=$ Banyaknya kategori yang dipilih penilai (dalam hal ini $=5$ ) $r r=$ Skor yang diberikan dari penilai; $\mathrm{n}=$ Banyaknya jumlah penilai. Uji praktikalitas yang dilakukan untuk melihat praktis atau tidaknya modul dilihat berdasarkan kategori praktikalitas pada Tabel 1 .

\section{HASIL DAN DISKUSI}

\subsection{Tahap Prototipe IV}

Uji praktikalitas pada uji coba kelompok kecil (small group) dilakukan setelah melalui tahapan dari penilaian para ahli pada prototipe III yang dihasilkan. Uji ini dilakukan pada 6 orang peserta

Tabel 1. Kategori Praktikalitas berdasarkan Aiken's V.

\begin{tabular}{c|c} 
Nilai V & Kategori \\
\hline$\leqslant 0,4$ & Kurang \\
\hline $0,4<\mathrm{V} \leqslant 0,8$ & Sedang \\
\hline $0,8<\mathrm{V}$ & Praktis
\end{tabular}

didik yang memiliki kemampuan berbeda. Peserta didik dipilih secara acak dengan bantuan dari guru kimia sekolah tersebut. Didapatkan nilai modul sebesar 77,00. Hasil uji praktikalitas pada kelompok kecil (small group) dapat dilihat pada Tabel 2.

Tabel 2. Hasil Uji Praktikalitas Kelompok Kecil (Small Group).

\begin{tabular}{l|c|c} 
Aspek yang dinilai & Aiken's V & Kategori \\
\hline $\begin{array}{l}\text { Kemudahan } \\
\text { Penggunaan }\end{array}$ & 0,89 & Tinggi \\
\hline $\begin{array}{l}\text { Efisiensi Waktu } \\
\text { Pembelajaran }\end{array}$ & 0,90 & Tinggi \\
\hline Manfaat & 0,85 & Tinggi \\
\hline Rata-rata V & $\mathbf{0 , 8 8}$ & Tinggi
\end{tabular}

Berdasarkan tabel dapat disimpulkan bahwa kemudahan penggunaan modul asam basa Aiken's V 0,89 dengan tingkatan tinggi. Berarti modul asam basa berbasis inkuiri terbimbing yang dikembangkan mengenai petunjuk penggunaan modul, bahasa, materi, dan soal-soal dalam modul dapat dipahami dengan baik oleh peserta didik.

Efisiensi waktu belajar pada modul asam basa Aiken's V 0,90 dengan tingkatan tinggi. Menandakan bahwa modul asam basa berbasis inkuiri terbimbing yang dikembangkan ukuran modulnya praktis dan dapat digunakan berulang-ulang. Manfaat dengan adanya modul asam basa Aiken's V 0,85 dengan tingkatan tinggi. Menunjukkan modul dengan berisikan gambar, model, soal-soal dapat meningkatkan motivasi peserta didik menemukan konsep, dan menumbuhkan keaktifan peserta didik dalam pembelajaran.

Uji kelompok kecil (small group) secara keseluruhan mengenai modul asam basa dengan nilai kepraktisan 0,88 dengan kategori tinggi. Sehingga modul sudah menarik dari segi cover, tampilan warna, dan model/gambar serta membuat peserta didik dapat memahami dan aktif dalam pembelajaran melalui langkah-langkah yang terdapat pada modul berbasis inkuiri terbimbing.

Data ini menandakan bahwa modul asam basa berbasis inkuiri terbimbing sudah praktis dan sudah lebih baik digunakan ${ }^{[17]}$. Hal ini sesuai dengan peneliti sebelumnya bahwa pada uji kelompok kecil ini membuat peserta didik secara aktif berdiskusi, aktif memberikan tanggapan melalui bahan ajar yang memiliki tampilan dan desain yang menarik ${ }^{[18]}$. Desain cover dari modul asam basa melalui Gambar 1 .

\subsection{Tahap Penilaian}

\subsubsection{Uji praktikalitas guru}

Berdasarkan data yang diperoleh dapat dikatakan bahwa modul berbasis inkuiri terbimbing yang dihasilkan telah memiliki tingkat kepraktisan yang tinggi dari segi ketertarikan dan kemudahan penggunaan pada modul. Hal ini sesuai menurut 


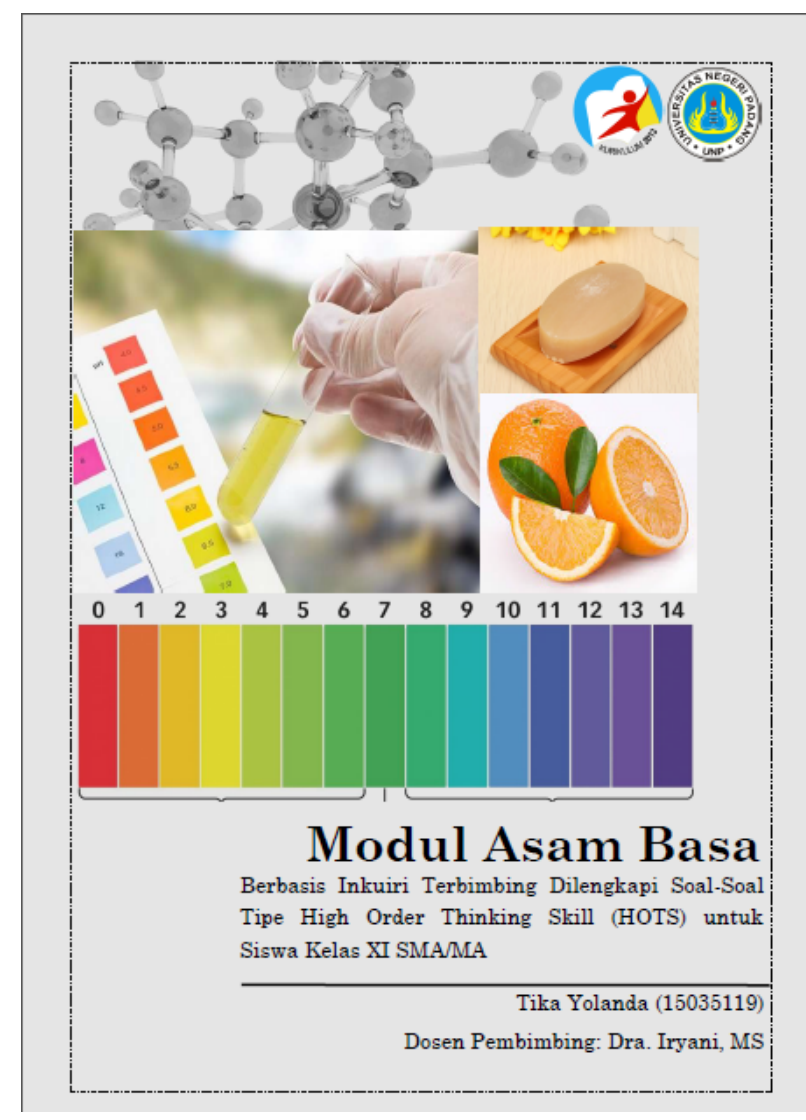

Gambar 1. Cover Modul.

peneliti sebelumnya bahwa kepraktisan berkaitan dengan kesukaan dan kemudahan bagi pengguna sehingga berpengaruh terhadap capaian pembelajaran peserta didik pada produk yang dihasilkan ${ }^{[19]}$. Hasil uji praktikalitas pada guru dapat dilihat pada Tabel 3.

Tabel 3. Hasil Uji Praktikalitas pada Guru.

\begin{tabular}{l|c|c} 
Aspek yang dinilai & Aiken's V & Kategori \\
\hline $\begin{array}{l}\text { Kemudahan } \\
\text { Penggunaan }\end{array}$ & 0,92 & Tinggi \\
\hline Efisiensi Waktu Belajar & 0,88 & Tinggi \\
\hline Manfaat & 0,88 & Tinggi \\
\hline Rata-rata V & $\mathbf{0 , 8 9}$ & Tinggi
\end{tabular}

Hasil analisis data dari uji praktikalitas oleh guru didapatkan bahwa kemudahan penggunaan modul dengan nilai 0,92 dimana sudah menggunakan petunjuk dan langkah-langkah pembelajaran inkuiri yang mudah dipahami. Efisiensi waktu belajar dengan nilai 0,88 terhadap kecepatan belajar sudah baik. Manfaat menggunakan modul asam basa berbasis inkuiri terbimbing dengan nilai 0,88 ditandai sudah adanya pertanyaan kunci, lembar evaluasi dan lembar kerja yang dapat meningkatkan pemahaman peserta didik.

Hasil dari keseluruhan diperoleh nilai Aiken's V sebesar 0,89 dengan kategori tinggi. Berdasarkan hasil analisis data yang didapatkan disimpulkan bahwa modul asam basa berbasis inkuiri terbimbing memiliki tingkat kepraktisan yang tinggi. Kepraktisan modul didapatkan dari segi kemudahan dan kemampuan penggunaan dari modul.

\subsubsection{Uji praktikalitas peserta didik}

Uji lapangan (field test) dilakukan pada saat dihasilkan prototipe IV. Hasil uji lapangan diperoleh nilai sebesar 0,89 dengan kategori tinggi. Uji praktikalitas dilakukan dengan memilih tingkatan kemampuan peserta didik yang berbeda terhadap tiga kelas, yaitu XI MIPA 1, XI MIPA 2 dan XI MIPA 3. Masing-masing kelas akan dipilih 15 orang yang akan mengerjakan dari modul yang diberikan dan didapatkan nilai sebesar 77,0. Demikian dapat dikatakan bahwa penilaian dari angket respons peserta didik mempunyai hubungan dengan nilai yang didapatkan dari jawaban pada modul yang dijawab peserta didik. Hasil uji terdapat pada Tabel 4.

Tabel 4. Hasil Uji Praktikalitas pada Peserta Didik.

\begin{tabular}{l|c|c} 
Aspek yang dinilai & Aiken's V & Kategori \\
\hline $\begin{array}{l}\text { Kemudahan } \\
\text { Penggunaan }\end{array}$ & 0,90 & Tinggi \\
\hline Efisiensi Waktu Belajar & 0,91 & Tinggi \\
\hline Manfaat & 0,88 & Tinggi \\
\hline Rata-rata V & $\mathbf{0 , 8 9}$ & Tinggi
\end{tabular}

Hasil dari uji praktikalitas pada peserta didik didapatkan modul dari segi kemudahan penggunaan sudah menggunakan bahasa, huruf, dan tahapan pembelajaran yang menuntun peserta didik belajar secara mandiri ${ }^{[20]}$. Efisiensi waktu belajar sudah menggunakan waktu yang baik. Manfaat menggunakan modul disertai dengan model yang menarik motivasi peserta didik dalam pembelajaran ${ }^{[21]}$.

Modul asam basa berbasis inkuiri terbimbing dapat menarik motivasi belajar peserta didik selain dari segi gambar, desain dan modelnya, juga memiliki lembar kegiatan dan lembar evaluasi berupa soal-soal yang dapat meningkatkan pemahaman peserta didik. Lembar kerja berisikan langkah-langkah inkuiri terbimbing, sehingga menuntun peserta didik menemukan konsep. Pada praktiknya setelah peserta didik memahami materi, selanjutnya menjawab soal-soal pada lembar evaluasi, agar peserta didik lebih memahami materi yang dipelajari. Desain Lembar kegiatan dan Lembar evaluasi dapat dilihat pada Gambar 2.

Penilaian pada modul dan angket respons yang dijawab oleh guru dan peserta didik saling keterkaitan dalam menentukan kepraktisan modul. Sehingga dapat dikatakan bahwa penggunaan modul asam basa berbasis inkuiri terbimbing dapat membantu peserta didik dalam menemukan konsep dan mengaplikasikannya ke dalam bentuk soal-soal latihan. 


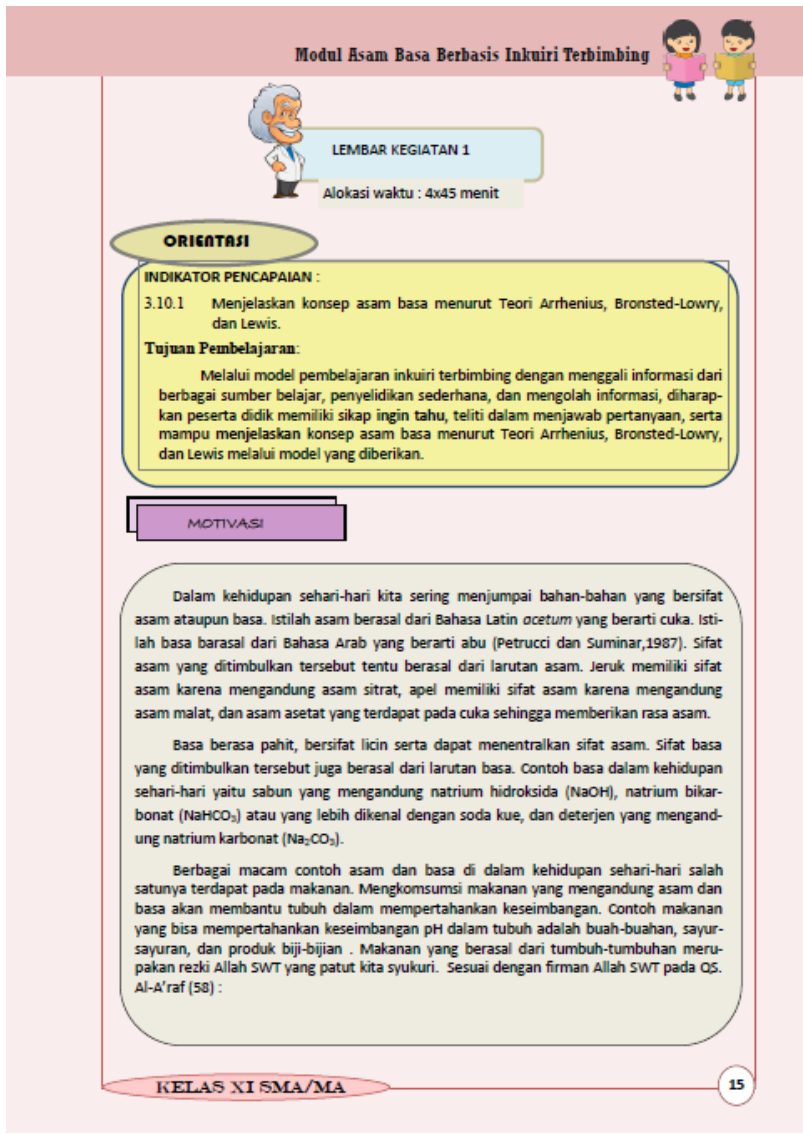

Gambar 2. Lembar Kegiatan dan Lembar Evaluasi.

Uji praktikalitas pada guru dan peserta didik yang diperoleh sesuai dengan peneliti sebelumnya bahwa dengan menggunakan modul berbasis inkuiri mampu mempermudah peserta didik dalam memahami materi yang diajarkan. Modul berisikan langkah-langkah inkuiri terbimbing yang menuntun peserta didik belajar mandiri, sehingga guru menuntun peserta didik dalam mempelajari modul dengan baik ${ }^{[22]}$.

Modul dapat dikatakan praktis sesuai dengan peneliti sebelumnya bahwa pada suatu penelitian mengenai produk yang dikembangkan dikatakan praktis apabila praktisi dan para ahli menyatakan produk secara teoritis diterapkan di lapangan memiliki kategori baik. Modul dapat menuntun peserta didik menemukan konsep dari soal-soal yang dipelajari. Kemudahan dan kejelasan peserta didik dalam memahami konsep pada modul dapat ditinjau berdasarkan jawaban pertanyaan dari modul[23]. Berikut hasil keseluruhan mengenai uji lapangan (field test) pada guru dan peserta didik dapat dilihat pada Gambar 3.

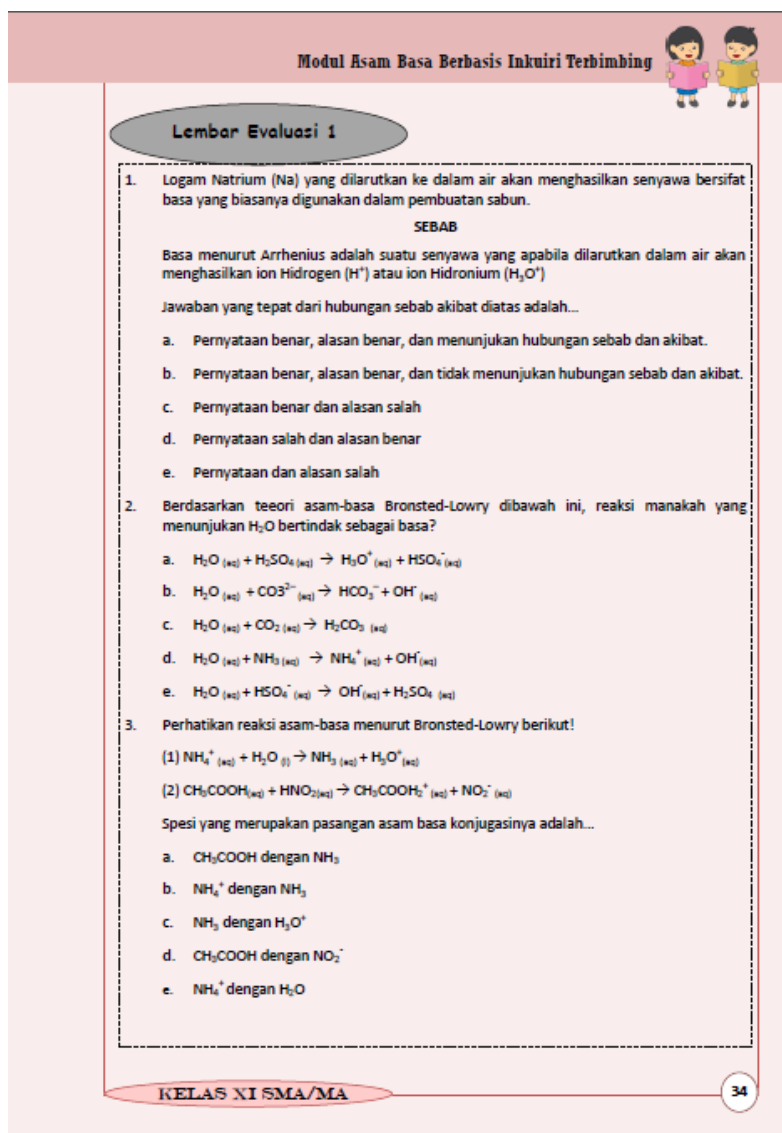

\section{SIMPULAN}

Hasil dari penelitian yang telah dilakukan didapatkan bahwa nilai kepraktisan modul asam basa berbasis inkuiri terbimbing sebesar 0,89 dengan kategori tinggi. Sehingga modul praktis dan dapat digunakan di sekolah.

\section{REFERENSI}

1. Kementerian Pendidikan dan Kebudayaan.

Peraturan Menteri Pendidikan dan Kebudayaan

Nomor 36 Tahun 2018 tentang Perubahan atas

Peraturan Menteri Pendidikan dan Kebudayaan

Nomor 59 Tahun 2014 tentang Kurikulum 2013

Sekolah Menengah Atas/Madrasah Aliyah.

Permendikbud 2018;1-12.

2. Asda EF, Iryani I. Validitas dan Praktikalitas

Modul Titrasi Asam dan Basa Berbasis Inkuiri

Terbimbing dilengkapi Soal-Soal Tipe HOTS .

Edukimia 2020;2(1):12-7.

3. SC P, Maimunah M, Hutapea NM.

Pengembangan Perangkat Pembelajaran

\section{Nilai Rała-Rała Aiken's V dari Praktikaliłas Guru dan Peserta Didik Terhadap Modul Asam Basa Berbasis Inkuiri Terbimbing}

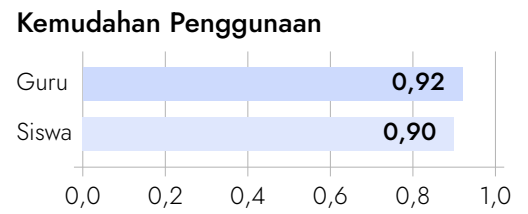

Gambar 3. Grafik Praktikalitas.
Efisiensi Waktu Belajar

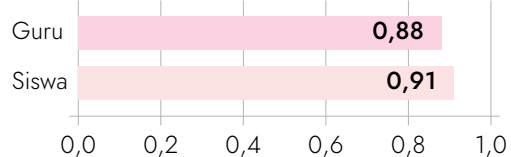

\section{Manfaat}

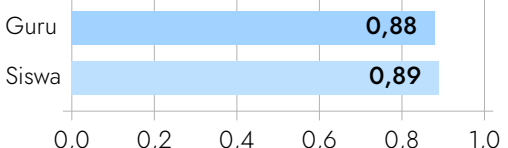


Matematika Menggunakan Pembelajaran

Berbasis Masalah Untuk Memfasilitasi

Pemahaman Matematis Peserta Didik. Jurnal Cendekia: Jurnal Pendidikan Matematika 2020;4(2):800-812.

4. Praptiwi L, Sarwi, Handayani L. Efektivitas Model Pembelajaran Eksperimen Inkuiri Terbimbing Berbantuan My Own Dictionary Untuk Meningkatkan Penguasaan Konsep Dan Unjuk Kerja Siswa Smp Rsbi. Unnes Science Education Journal 2012;1(2).

5. Rahayu S, Iryani I. Validitas dan Praktikalitas Modul Kesetimbangan Ion dan pH Larutan Garam Berbasis Inkuiri Terbimbing. Edukimia 2020;2(1):44-50.

6. Ikhwan H, Mawardi. Pengembangan Lembar Kerja Peserta Didik (LKPD ) Berbasis Inkuiri Terbimbing Untuk Meningkatkan Keterampilan Berfikir Kritis pada materi Sifat Koligatif Larutan. Ranah Research. 2010;2(4):113-118.

7. Mellyzar M. Persepsi Guru Dan Siswa Terhadap Modul Kimia Berbasis Inkuiri Terbimbing pada Materi Reaksi Redoks dan Tata Nama Senyawa. Jurnal Pendidikan Dan Pembelajaran Sains Indonesia (JPPSI) 2021;4(1).

8. Iryani, Bayharti, Iswendi, Putra RF. Effect of Using Guided Inquiry-Based Chemical Bonding Modules on Student Learning Outcomes. Journal Physics: Conference Series 2021;1788(1).

9. Bahri YR, Iryani I. Validitas dan Praktikalitas Modul Reaksi Oksidasi Reduksi Berbasis Inkuiri Terbimbing Dilengkapi Soal High Order Thinking Skill (HOTS) untuk Siswa Kelas X SMA/MA. Edukimia 2020;2(2):65-70.

10. Andromeda A, Ellizar E, Iryani I, Bayharti B, Yulmasari Y. Validitas dan Praktikalitas Modul Laju Reaksi Terintegrasi Eksperimen dan Keterampilan Proses Sains untuk Pembelajaran Kimia di SMA. Journal Eksakta Pendidikan (JEP) 2018;2(2):132.

11. Syamsu FD. Pengembangan Penuntun Praktikum IPA Berbasis Inkuiri Terbimbing Untuk Siswa Smp Siswa Kelas VII Semester Genap.Ilmiah Pendidikan Biologi 2017;4(2):13-27.

12. Artika PI, Bayharti. Pengembangan Modul Hidrolisis Garam Berbasis Guided Discovery Learning Untuk Peserta Didik Kelas XI SMA / MA Development of Salt Hydrolysis Module Based on Guided Discovery. Edukimia 2021;3(1).

13. Harahap AR, Bayharti. Pengembangan Modul Laju Reaksi Berbasis Guided Discovery Learning untuk Kelas XI SMA/MA. Edukimia 2021;3(1).

14. Permatasari W, Yerimadesi Y. Analisis Validitas dan Praktikalitas dari Modul Minyak Bumi Berbasis Guided Discovery Learning. Edukimia 2020;2(1):25-31.

15. Fadhillah F, Andromeda A. Validitas dan Praktikalitas E-Modul Berbasis Inkuiri Terbimbing Terintegrasi Laboratorium
Virtual pada Materi Hidrolisis Garam kelas XI SMA/MA. Journal Eksakta Pendidikan 2020;4(2):179.

16. Retnawati H. Analisis Kuantitatif Instrumen Penelitian. Yogyakarta : Parama Publishing, 2016.

17. Sari YP, Gazali F. Validitas dan Praktikalitas Modul Hukum-Hukum Dasar Kimia Berbasis Pendekatan Saintifik dengan Menerapkan Teknik Probing Prompting untuk Siswa Kelas X SMA/MA. Edukimia 2019;1(2):39-45.

18. Zuriati Z. Penerapan Metode Small Group Discussion Dalam Pembelajaran Pendidikan Agama Islam: Dampak Terhadap Peningkatan Prestasi Belajar Peserta Didik Kelas X SMA. Sosiohumaniora Journal Ilmiah Ilmu Sosial dan Humaniora 2018;4(1):71-77.

19. Suastika, I Ketut \& Rahmawati A. Pengembangan Modul Pembelajaran Matematika Dengan Pendekatan Kontekstual. Journal Pendidikan Matematika Indonesia (JPMI). 2019;4(2):58-61.

20. Cheva VK, Zainul R. Pengembangan E-Modul Berbasis Inkuiri Terbimbing Pada Materi Sifat Keperiodikan Unsur Untuk Sma/Ma Kelas X. EduKimia 2019;1(1):28-36.

21. Sari MP, Azhar M. Pengembangan Modul Perhitungan Rumus Kimia dan Persamaan Reaksi Berbasis Inkuiri Terstruktur dengan Tiga Level Representasi untuk Kelas X SMA/ MA. Edukimia 2019;1(2):46-52.

22. Ayu NA. Pengembangan Modul Elektronik Biologi Berbasis Inkuiri Terbimbing pada Kelas XI Semster I di SMAN 1 Padang Ganting. Repository; Publikasi IAIN Batusangkar

23. Andromeda, Alfirahmi. Pengembangan Modul Termokimia Berbasis Inkuiri Terbimbing Terintegrasi Eksperimen untuk Kelas XI SMA/ MA. Menara Ilmu 2018;12(12):9-18. 